Article

\title{
Sprouts of the Body, Sprouts of the Field: Identification of the Goddess with Poxes in South India
}

\author{
Perundevi Srinivasan \\ Religious Studies, Siena College, Loudonville, NY 12211, USA; psrinivasan@siena.edu
}

Received: 1 January 2019; Accepted: 22 February 2019; Published: 27 February 2019

\begin{abstract}
In south India, when a person is afflicted with poxes of any variety, it is believed that the goddess Mariyamman has "arrived" in the person. The Tamil term "ammai" means pustules or "pearls" of poxes as well as mother/goddess. Indigenous discourses, gleaned from resources, such as songs and narratives, facilitate our interrogation of the Hindu "religious experience" that underscores the immanent and eminent manifestations of the deity and the dimension of benevolence associated with pox-affliction. Asking what might be the triggering conditions for identifying the pox-afflicted body as the goddess, I problematize the prevalent scholarly characterization of such affliction in terms of "possession" of a body, taken as a "mute facticity," by an external agent, namely, the goddess. Drawing from ethnographic sources and classical Tamil texts, I argue that the immanent identification of the body as the goddess and conceptualization of her sovereign authority over the body during affliction are facilitated by an imagistic relationship of the afflicted body with an agricultural field, which is conventionally regarded as feminine in the Tamil context.
\end{abstract}

Keywords: Mariyamman; ammai; poxes; affliction; Tamil; religious experience; Hinduism; rain; agricultural field; goddess

\section{Introduction}

On a summer afternoon many years ago, I lay stretched out on my mother's cotton sari, writhing from excruciating pain throughout my body. I had high fever for a couple of days, and it was on the third day that round pustules of chickenpox began to erupt and spread all over my body. My mother was in two minds whether to consult a doctor, since in Cuddalore town in the southern state of Tamilnadu, where I lived then, people did not normally go to an allopathic doctor to seek a cure for poxes. After hours of discussion with my father and neighbors, my mother asked a physician to visit our house. He confirmed that ammai (meaning both poxes and the divine mother/goddess in Tamil) had 'arrived' in my body in the form of chickenpox, and he would not, therefore, prescribe any medicine other than Crocin (paracetamol) pills to bring down the fever, though he assured us that I would be alright within a week. Even after the doctor's visit, my mother was not fully convinced about giving me what she called "English" (allopathic) medicine. Pleading with the goddess to forgive her for treating me with allopathic medicine, and after profusely requesting the goddess to "descend" from the body - all these pleadings and requests were actually addressed to me, although a few distant abodes of Mariyamman in Tamilnadu were also mentioned-my mother finally decided to give me only a single Crocin (Paracetamol) pill. When I recall that experience of ammai now, even after all these years, I am still overwhelmed by a strange blend of smells: of margosa leaves, of turmeric, and my mother's sari; along with them, the smell of pustules with oozing matter that had appeared all over my body and were regarded as manifestations of the goddess herself. 
Mariyamman's relationship with ammai is considered at three levels among Hindus in Tamil culture. First, the goddess is believed to be involved with the occurrence of ammai. For instance, "The mother has played" ("amma vilaiyadiyirukka") is a way in which the ailment is talked about. At the second level, the goddess and pustules are one and the same, and I will discuss them early in this article. At the third level, the goddess is believed to have the power to cure poxes. Several songs of the goddess in various genres, like Talattu (Lullaby), Unjal (Swing), and Varnippu (Description) extol the goddess for this power. Usually, when the first "pearls" become visible on the body of a person, a bunch of margosa twigs is hung on the doorway of the afflicted person's house to indicate the "presence" of the goddess who has arrived there, inaugurating a set of customary habitual practices (palakkavalakkam), which are both restrictive and mandatory in nature. ${ }^{1}$ For instance, engaging in sexual activities, sleeping on a mattress, cutting hair, shaving, entertaining visitors, seasoning the food with mustard seeds, and wearing slippers, are prohibited in the house, as they are considered offensive to the goddess. A pot of water is kept near the afflicted person, and the house is meticulously cleaned every day. Occasionally, a lullaby song to Mariyamman, available in the form of a chapbook, is sung by a family member who addresses the song to the pox-afflicted person. People do not normally visit a physician seeking a cure of poxes. Instead, a vow of obligation is taken in the name of Mariyamman, in order to persuade the goddess to "descend" from the body at the earliest. In east and south east Tamilnadu, especially in and around Tanjore, Pudukkottai and Sivaganga, when the affliction is severe, a traditional healer (ammappillai, meaning "child of the 'mother' /goddess") is invited to visit the house regularly and recite the goddess's songs, towards seeking the goddess's grace for curing the poxes quickly.

How can one understand the identification of a pox-afflicted body as a female deity Mariyamman? What could be the triggering conditions in which the goddess is perceived as the source of poxes, as the one who heals poxes, while she is considered poxes as such? These questions, which have stemmed from my experience of pox-affliction, increasingly occupied my mind when I started working on Mariyamman worship practices in Tamilnadu. Exploring these questions might afford us a glimpse of a specific mode of "religious experience," relating to the goddess Mariyamman, who is considered in her immanent and eminent forms in the event of pox-affliction in Tamilnadu. Here, I must clarify my use of the term "religious experience." While I agree with the argument that there is a pertinent place always accorded to "indigenous religious experience" in Hindu traditions, I also tend to understand that such "experience" is historically constituted, and it is a "correlation between fields of knowledge, types of normativity and forms of subjectivity in a particular culture." ${ }^{2}$ In the case of Mariyamman worship and pox-affliction, some of the related "fields of knowledge" include those pertaining to illnesses and healing techniques along with those related to institutionalized temple worship. Similarly, as I have discussed elsewhere, Mariyamman worship practices related to pox-affliction are replete with two key inter-related discursive tropes, karpu (chastity of women) and cuttam (purity-cleanliness), and habitual practices, organized around these two tropes, reinforce the heteronormative power apparatus. ${ }^{3}$ Further, I think the mode of religious experience could also be a mode of "actualization" of the divine/ deity. In the instance of pox-affliction, the religious experience could be a mode in which

For an analysis of the habitual practices followed during pox-affliction, see (Srinivasan 2009, pp. 97-142).

June McDaniel, in an article, contests a range of critical perspectives that deny "indigenous value on religious experience," and draws attention to distinct terminology and specific ideas that articulate such "experience" in diverse Hindu traditions, including Dharma, Bhakti, Tantra, and folk traditions. See (McDaniel 2009). In framing my take on "religious experience," I have benefited from Foucault's discussion of "experience" in the realm of sexuality in modern Western societies. Foucault defines "experience" as that which has "caused individuals to recognize themselves as subjects of a 'sexuality,' which was accessible to very diverse fields of knowledge and linked to a system of rules and constraints." See (Foucault 1985, p. 4). Further, I think religious experience, like "experience" in the realm of sexuality, is constituted historically, and belongs to an order or "reality" than that of "truth." See (Foucault 1991, p. 36).

3 (Srinivasan 2009, pp. 209-60). 
the goddess is "actualized" as the body of the afflicted person and as an autonomous force through various habitual signifying practices of the community. ${ }^{4}$

The indigenous discourses which I am analyzing in the article form part of the repertoire of such collective practices centred on Mariyamman worship and pox-affliction. Specifically these discourses are gleaned from narratives and songs of devotees and healers in the districts of Pudukkottai, Dindigul, Chennai, and Sivaganga in Tamilnadu, which I gathered during my ethnographic fieldwork (2004-2006). I also refer to my personal conversations with devotees. I employ Mariyamman songs, copied from palm-leaf manuscripts and from published books, in addition to Tamil classical literary texts for the purpose of my genealogical analysis. My concern is to interrogate the indigenous discourses in order to schematically unearth the identification of an afflicted body as the divine/goddess, and in the process, problematize the prevalent notions of pox-affliction in terms of "possession" by an external agent, namely, a spirit or deity. ${ }^{5}$ I hesitate to buy into the academic idiom of "possession," since it amounts to considering the goddess as an a priori source of affliction. Instead, I engage with the task of understanding how the immanent and eminent "presence" of the goddess is "normatively" established during the instance of affliction, and in doing this, I critically engage with emic references to poxes as well. ${ }^{6}$ In addition, I seek to bring out the creative and aesthetic investment of Tamil culture in its forging discursive connections between the body and the landscape, and between poxes, pearls, pulses and grains. This may provide a counter-narrative to symbolic and functionalist interpretations of the religious dimension of the disease as representing and serving some other external reality, such as the devotee's poverty or marginalization or fear. ${ }^{7}$

\section{Understanding the Body as and of the Goddess}

In the Tamil popular discourse and folk songs, sometimes ammai is portrayed as a "play" or "sport" of the goddess. " "The mother has played around" (amma vilaiyadiyirukka) is a common place expression that indicates the "arrival" of poxes on a person. ${ }^{9}$ The Tamil term "ayi muttu," meaning "mother pearl," refers to both the goddess and the lesion or pustule of ammai. The pus or putrid matter oozing from the lesion is called "mother's milk" (ammaippal). In the folk song of Mariyamman Talattu, sung to the afflicted person, the goddess is addressed as the mother with milk oozing from her breasts, alluding to the oozing pustules. ${ }^{10}$ Another folk song on the goddess, Mariyamman Varnippu ("Description of Mariyamman") also contains a similar evocation:

4 For a theoretical inquiry into the mode of "actualization" of the goddess through performative and signifying practices, refer to (Srinivasan 2009, pp. 14-19).

5 Throughout this article, I use the term "discourses" following Foucault. According to Foucault, the discourses are not just "groups of signs (signifying elements referring to contents or representations) but as practices that systematically form the objects of which they speak." See (Foucault 1972, p. 49).

6 I use the term "normative" expanding the sense in which Judith Butler uses it to mean the "norms that govern gender." For Butler, the term is indicative of "ethical justification, how it is established, what concrete consequences proceed there from." See (Butler 1999, p. xx). In the present context of discussion, I employ it to draw attention to the cultural norms that govern the association of the affliction with the goddess.

7 For a symbolist approach to Mariyamman's association with smallpox, see (Egnor 1984). According to Margaret Trawick Egnor, before its eradication, smallpox together with its religious underpinnings served as a "convenient symbol" for grim realities, such as "the pain and stigma of poverty", "family discord", and "crowded living conditions". For a functionalist interpretation of the association of the goddess with smallpox, see (Arnold 1993). For David Arnold, religion in the form of goddess worship was a way in which local people tried to make sense of the "destructive" and "fearful" smallpox.

8 This is one of the ways in which the pox-affliction is referred to. There are certain other phrases that may be used to refer to the affliction, which I discuss in the course of this article.

9 (Srinivasan 2009, pp. 79, 117). Also see (D 1747, lines 93-104), discussed in this paper. The aspect of "divine play" ("khelna") that underscores the theme of "parental love" of the deity for the devotee is a discernible theme in the rituals of "Goddess possession" in Panjab as well, as pointed out by Kathleen Erndl. See (Erndl 1993, p. 108). The songs of the healers, which form part of the healing performances of poxes that I have attended in Pudukkottai district, contain the repetitive address of the afflicted person as a "child", thereby emphasizing the benevolent, motherly aspect of the goddess as she was asked to be compassionate to the afflicted person.

10 (Mariyamman Talattu, n.d., p. 8). When I use printed texts such as this book, I cite the page numbers. In addition to printed texts, I also cite palm leaf manuscripts. In the latter case, I provide the corresponding line numbers. Mariyamman Talattu is available as both printed and palm leaf manuscript versions, and I use them both for the purpose of my analysis. The palm 
The stringed pearls dance, milk oozes from the two breasts,

Devi, you grant boons to the deserving. ${ }^{11}$

The body with ammai is not merely a "sacred" body; it is the body as and of the goddess. Also, if we look at textual sources, such as songs about the goddess, ethnographic narratives, and personal conversations, we constantly encounter portrayals of ammai as being a benevolent state, indicating Mariyamman's grace or affection. For instance, local healers of the affliction insist that the goddess visits the house in the form of ammai in order to thwart an evil or tragedy which might otherwise befall the family. According to the healers, ammai is a protective gesture of the goddess preempting the bad fortune, which is otherwise in store for the family. Muthukkannu, a healer I met in a village called Vagaippatti near Pudukkottai in the year 2004, explained the "protection" offered by the goddess:

Ammai does not come without a reason. She comes only to save us. Only when ... planets are not placed well in our horoscope, and they show wrath toward us, then based upon our karma punniyam (merit of karma or past deeds) and dharmam (rightful deeds/virtue), the goddess, the mother who has begotten us would think, "Oh, these planets are going to attack my child." She would come and descend into us so that the planets run away. The planets approach a house like a stone. But upon seeing the goddess, who has already arrived there (in the form of pustules), they would be afraid of thinking she has a thousand eyes and go away. ${ }^{12}$ Then everything would be fine.

Similarly, Mariyamman Talattu also emphasizes the affection of the goddess for human beings. The goddess with "compassion" is believed to arrive in the form of pearls in order to dwell in the "poor one."13 The body with ammai, being described as a "golden swing" or "palanquin," seems to have achieved this state due to the "devotion" felt toward the goddess:

Has she stood as a blessing in the form of a golden swing?

Has she given this boon and protected me

Thinking that "she is a devotee," and bestowing me with this palanquin? ${ }^{14}$

I would like to clarify that despite such glorifying remarks, people in Tamilnadu by no means seek to 'invite' any kind of poxes upon them. In fact, in the songs, related to the goddess and poxes, we do come across allusive references comparing pox-affliction, which is attributed to the goddess, with snake-bite and poison. ${ }^{15}$ The unbearable pain and suffering caused by poxes are vividly articulated in the songs. Poxes fall very much within the Tamil discursive ambit of affliction or illness, and when someone has poxes, it is expressed that her "health is unwell" ("udambu cariyillai") as one has any other kind of illness such as fever. Also, when a person is afflicted with poxes, at times, ammappillai healers are asked to visit their home for singing Mariyamman songs to enable a quick cure,

leaf manuscript version of this song as well as other songs were copied from the Government Oriental Manuscripts Library in Chennai, Tamilnadu, and they are cited by their number, beginning with the letter " $\mathrm{D}$," as per the records of the Library. 11 (D 2164, lines 24-25).

12 "The thousand-eyed" or "Ayiram Kannudaiyal" is an epithet for Mariyamman. A few other healers whom I met in places such as Mukkannamalaippatti and Thayamangalam (2005-2006) expressed a similar view concerning the 'arrival' of the affliction. See (Srinivasan 2009, p. 429).

13 (D 1747, lines 95-96). One can compare this with the "traditional" perception of the disease in the Bible. David E. Shuttleton observes that the eruptive disease that Job suffered was cited by theologians of the early eighteenth century to argue against smallpox inoculation because it was the devil that gave forth the "inflammatory pustules" upon Job. See (Shuttleton 2007, p. 63). Notwithstanding the conflation between original smallpox and its antidotal inoculation, the association of pustules with the devil strikes a different tone from the south Indian perception of the affliction. I should also mention here that goddess Sitala, who is associated with poxes in North as well as Eastern India, has a more limited role compared to Mariyamman. For instance, Sitala is not connected with rains, and nor is she considered as a goddess

14 (Ibid., lines 106-8). protecting a territory as Mariyamman is considered. See (Wadley 1980, p. 57).

15 (Srinivasan 2009, p. 162). 
as I mentioned before. ${ }^{16}$ Nevertheless, the affliction has discernible positive cultural connotations, and particularly I would like to focus on them to bring out the complex cultural nuances.

Prima facie, the Tamil conception of ammai as benevolence bestowed by the goddess does not fit with the scholarly framework, which discriminates between "possession" caused by malevolent spirits and by deities, espoused in binary terms of "affliction/punishment" and "gift/grace" respectively. ${ }^{17}$ Kathleen M. Erndl, for instance, points out such a distinction in the "theological and ritual context of the Goddess cult and popular Hinduism" in northern India, and observes that the former kind of possession is sought to be removed by "force or appeasement," while the latter kind is "usually encouraged or cultivated." ${ }^{18}$ In the Tamil context of ammai, as I mentioned before, the goddess's presence is not encouraged or cultivated, even though it is perceived as a gesture of grace. Further, I also hesitate to locate pox-affliction within the "models of possession," provided by Frederick M. Smith, who engages with "the field of possession" by dividing it into "positive" and "negative" possession. ${ }^{19}$ Even though Smith's category of "negative possession" is more inclusive since it includes "possession" by the deities as well, the benevolent dimension of the pox-affliction in the Tamil milieu, as discussed above, seems to destabilize this category. ${ }^{20}$

In the ethnographic literature that deliberates upon the connection of Mariyamman with poxes in terms of "possession," the affliction is often rendered in terms of "penetration" or "entry" of the goddess in her capacity as an external agent. For instance, Margaret Trawick Egnor has observed that the "smallpox goddess" Mariyamman "enters the body of a person out of 'desire' for them, love for them ...." ${ }^{\prime 21}$ Going along with Egnor, Isabelle Nabokov regards smallpox as "symbols" of "forceful penetration" of the goddess, which she also reads as a form of "sexual aggression."22 Pox-affliction is viewed as an instance of "involuntary possession" by the goddess by Willam Harman too. Harman states the goddess "enters a person's body" necessitating certain "ritual protocol" at home. ${ }^{23}$ Such perspectives of the goddess's downright occupation during pox-affliction, entailed by her "possession," resonates with the Judeo-Christian perspectives that inform the analytical category of "spirit possession," as pointed out by Mary Hancock. ${ }^{24}$ Hancock in her ethnographic study, which engages with "goddess mediums" in Chennai, observes that this category "tends to misinterpret the phenomena that it purports to explain," since it places the "goddess's coming to a devotee" on par with "a 'demonic' visitation," and assumes a "straightforward" claim of a person by the deity.

16 For a discussion on such healers in see (Srinivasan 2009, pp. 420-34). Here I am reminded of Carla Bellamy's observations with respect to practices related to haziri, "a form of spirit possession." She argues even though "the categories of physical and spiritual" in some religious traditions may not be clearly demarcated as in "the contemporary West," a denial of distinction between the categories "eliminates a distinction that is vital to the process through which most of those afflicted with haziri are healed." See (Bellamy 2008, pp. 31,35). The poxes are the goddess, and, at the same time, as an illness, they also need to be healed. The pain that they cause cannot be subsumed under the "sacredness" attributed to the body during the affliction.

17 (Erndl 1993, p. 106).

18 Ibid

19 (Smith 2011, p. 4).

20 Ibid. For Smith, "positive possession" is "constituted, oracular, and invited" and is attributed mostly to deities, "negative possession is normally disease-producing and is attributed to uninvited ethereal agents," which include spirits and deities.

21 See (Egnor 1984, p. 26).

22 According to Nabokov, the goddess "lodges herself 'inside' her victims' body" by this act. See (Nabokov 2000, p. 28).

23 (Harman 2011, p. 194).

4 (Hancock 1995, p. 173).

25 In the early anthropological literature on popular religion in Tamilnadu, we come across a conflation of female deities with demons. For instance, see (Caldwell 1887, p. 94), for Rev. Robert Caldwell's derisive views on the worship of female deities (Ammans) in relation to pestilences:

Notwithstanding the superior dignity attributed to the Ammans, I question whether they are not, after all, more diabolical than the professed devils. Cholera and small-pox, the most dreadful of all pestilences, are inflicted by them alone; and what is specially extraordinary is, that small-pox is invariably called by the common people 'the sport of the Amman.' When a person is stricken by small-pox the expression the people use is 'the Amman is taking her pastime over him.' ... There is no difference between the Ammans and the devils in regard to their appetite for blood. 
The category, she explains, "derives from Euro-Western legal understandings of property ownership and alienability," underscoring the idea of "individual subjectivity," which can be owned or controlled by the deity. ${ }^{26}$ Critiquing such perspectives underlying "spirit possession," she gives a list of a range of Tamil terms, such as "eru" (to mount), "kattu" (to bind), and "parru" (to get attached), which inform otherwise," as these terms indicate "attachments among humans, between humans and inanimate objects, and between humans and deities," emphasizing "biomoral connectedness and/or exchanges of energies." 27

Even though none of these Tamil verbs, listed by Hancock, are used in referring to pox-affliction in Tamilnadu, I concur with Hancock that the category of "spirit possession" implying an external agent or force "entering" and occupying the body is problematic in the context of pox-affliction as well. Especially, from what I have heard from my interlocutors, a manifestation of poxes is not always perceived so. In this regard, a Tamil expression, which is used to refer to affliction, namely, "ammai vantirukku" meaning "ammai has arrived," merits attention. ${ }^{28}$ During my fieldwork in Tamilnadu, when I asked about the "source" of poxes, my conversationalists did not always interpret the "arrival" of poxes in terms of something emanating from the outside and ends up in the house and the body. According to some devotees of Mariyamman, the "arrival" amounts to "arriving from inside the body," and manifesting as pox-affliction externally. For instance, when I asked “Where does ammai come from?" Velmurugan, a singer, who plays utukkai (hour-glass shaped drum) at Mariyamman festivals, from Ulundurpet responded: "Ammai is inside the body. From inside it comes out on the body as pustules that can be seen with our naked eyes." To the same question, Kala, a devotee of Mariyamman, who resides in Vannanthurai, Besant Nagar, later explained: "Ammai comes from inside us." In reply to my follow-up question, "What is inside?" to her, she further explained: "Akka, ammai dwells in the stomach and it arrives from there."

Initially, such a complex account of the source of poxes tempted me to interpret it by employing a much nuanced interpretation of the indigenous Tamil conception of ananku that has been advanced by Alexander Dubianski. ${ }^{29}$ For Dubianski, ananku signifies both an inner "abstract power" and "a spirit,

I have discussed elsewhere how Caldwell's work "has set the tone of future ethnographies, relegate[ing] goddess worship to the discursive domain of the Dravidian," while equating it with "demonolatry," and how it carved a way for "advanc[ing] colonial civilizational rhetoric intervening in the field of 'religion' of 'natives.'" See (Srinivasan 2009, pp. 31-56).

26 (Hancock 1999, p. 173).

27 Ibid. In speaking of "attachments" and "connectedness," Hancock is influenced by the "transactional model" on "spirit possession," advanced by ethnosociologists, such as (Marriott and Inden 1977). In this model that emphasizes transaction of "substance-codes" and essences, "[T]he biomoral boundaries of the person are considered porous," and is prone "to the influences of place, food, cloth, and others' (including deities') bodies and their voiced and unvoiced intentions." See (Hancock 1999, p. 18). Frederick Smith also observes that the "transactional model" may be partly helpful in understanding the phenomenon of "possession," and writes, "[d]ividual persons, entities, or even concepts transfer parts or essences of themselves, in whole or in part, wilfully or by force, to other dividual persons, entities, or concepts" See (Smith 2006, p. 75). Applying the "transactional model" in his study on "possession" and citing a range of sources from classical literature of Vedic texts and Upanishads and the latter puranas, Smith tries to pinpoint that a transfer of "essences, akin to Marriott's coded substances," takes place in "a conscious or otherwise felt experience of possession." See (Smith 2006, p. 211). Elsewhere I have contested this model, because in this model "the body serves as a medium for the transfer of 'essences,' rather than playing an active role or having any primary significance in the process." See (Srinivasan 2009, pp. 402-4).

28 In an article, Hancock states that the transformed state of the female medium of the goddess is not described by her devotees as "avecam," which she notes, is "often glossed as spirit possession" (Ibid.). She explains since the condition of the medium was perceived as a "temporary transformation" by her devotees, it was rather expressed: "'the amman has come' (amman vantatu)." This is strikingly similar to the expression used to speak of pox-affliction. See (Hancock 1995, p. 89). I have also never heard of the term "avecam" being used to refer to pox-affliction either. Even in the temple festivals, where Mariyamman "arrives" in devotees, the term was not usually employed to speak of such condition. Similarly, based on certain Tamil terms employed to speak of the phenomenon, Kristin C. Bloomer distinguishes between "possession" by "benevolent deities and spirits," and the one by "'lesser spirits"” such as "those of deceased humans." See (Bloomer 2018, p. 9). According to her, the term "iranku" or "descend" is characteristic of the former kind of "possession." This particular term is also cited by Lynn Foulston to substantiate the goddess's "tak[ing] over the mortal body" as well. See (Foulston 2002, p. 145). Even though pox-affliction is regarded as an immanent manifestation of the goddess, the verb "iranku" is not employed to indicate the affliction, and, this again complicates the academic notion of the affliction in terms of "possession."

29 (Dubianski 2000, p. 8). 
an unidentifiable deity," with these meanings "closely interlocked in their usage ... ."30 Dubianski further qualifies this inherent "power" as a "natural power," which is distinct from a "supernatural" one, and proposes that since the expression of this power is "heat or/and fire," ananku could be perceived as being in the same order as that of tapas (severe ascetic practice), which produces an "ascetic heat." 31 Since poxes are said to be caused by bodily heat in popular discourse, one may consider the pox-affliction along the order of the power, articulated by the conceptions of ananku and tapas heat. This allows theorizing the affliction as a manifestation of the localized power immanent in the body and of the power of an eminent deity from outside. However, the conceptual framework of ananku is hardly adequate, because in the Tamil worldview, several other ailments (for instance, stomach ache, urinary infection, and certain eye diseases) are also attributed to accumulation of bodily heat, and, thus, the conception of ananku is not helpful to address why pox-affliction alone is perceived to be divine.

More importantly, my issue with the category of "spirit possession" is that it assumes a "mute facticity" of the body, which can be appropriated by an agent, be it a deity or a spirit. I have contested elsewhere that such consideration of the body as a "natural template or as an "unchanging material substrate" renders it a carrier of expressions of a psyche or self, "possessed" by an agent. ${ }^{32}$ I think that in the context of pox-affliction, the body cannot be understood as something other than that which is coded with the goddess's "presence." In advancing this argument, I follow Judith Butler's "critical genealogy" of the formulation of matter in articulating the body. ${ }^{33}$ Butler advocates "critical genealogy" in order to interrogate the assumed "biological" facticity of the body and to emphasize the body as produced by cultural norms and practices. According to Butler, matter "only appears under a certain grammatical form ... " or under a schema, which she further defines as a "principle of intelligibility." ${ }^{34}$ As the schema has always been implicated with the matter through which it "actualizes," schema and matter are discursively inseparable. "To matter'," Butler contends, is at once "to materialize" and "to mean" and, therefore, the "indissolubility of materiality and signification is no easy matter." ${ }^{35}$ Put simply, Butler shows how the perception of the body does not precede cultural intelligibility but always occurs in conjunction with it.

'While Butler's inquiry into schema concerns with the intelligibility of the body as a specific sex, as male or female, or as abject in general life scenarios, I think the method of "critical genealogy" of materiality is valuable and indispensable for analyzing the practices that characterize the goddess worship in connection with poxes. In fact, the Tamil word "porul" informs us of the epistemological indissolubility of materiality and meaning, which makes this discussion pertinent. ${ }^{36}$ The word denotes both "thing/matter" and "meaning/signification." When I say, "un porulaip parttukkol," it means "keep an eye on your thing;" when I say, "accollin porul enakkup puriyavillai," it means "I don't comprehend the meaning of that word;" and if I say "Aval ataip porutpaduttavillai," it means "She did not take it into cognizance/It did not matter to her."

\footnotetext{
Ibid.

(Ibid., p. 10).

For a more detailed discussion on this topic see (Srinivasan 2009, p. 402).

3 (Butler 1993, p. 13; Srinivasan 2009, pp. 14-19). Due to brevity of space, I cannot provide my entire discussion on this subject in this article.

34 Schema means "form, shape, figure, appearance, dress, gesture, figure of a syllogism and grammatical form." See (Butler 1993, p. 33). Butler notes that Aristotle did not make any "phenomenal distinction between materiality and intelligibility," and the entire phrase "the shape given by the stamp" is rendered in Greek by a single word—schema. As the schema has been implicated with the matter through which it "actualizes," the indissolubility, between schema and matter, implies that "[matter] only appears under a certain grammatical form," or under a schema, which she further explicates as a "principle of intelligibility." See (Butler 1993, p. 33).

35 (Butler 1993, pp. 30-32).

36 Analogous to the Western (Greek) philosophical tradition, the "indissolubility of materialization and signification" does not appear to be an "easy matter" in Tamil epistemological tradition either. I have pointed out this elsewhere drawing upon the Tamil text Tolkappiyam. See (Srinivasan 2009, pp. 16-17).
} 
Earlier I brought attention to the Tamil expression that denotes "the arrival of ammai," which complicates the theoretical paradigm of "possession;" yet, this expression still suggests an agent. However, the corporeal manifestation of the deity, suggested by emic references such as this, are complicated by another commonly used expression, "ammai varttirukku," which suggests an occurrence without attributing any agency. This particular expression implies a conception of "schema," in its articulating pox-affliction. The verb "varttal" means "casting/spreading in a mold." The act of "casting/spreading in the mold" with poxes, as the phrase indicates, configures the afflicted body as a "morphological possibility" with an inalienable shape or "schema." To put it succinctly, the "presence" of the goddess, perceived as poxes, operates as the "principle of intelligibility" during pox-affliction, and, with this coding principle, the afflicted body simultaneously materializes and is made sense of through discursive practices in the Tamil culture. ${ }^{37}$

In the event of pox-affliction, the goddess is not simply perceived corporeally, but she is accorded a sovereign status and is regarded as a super-human force who can cause and heal the affliction. One reference that categorically asserts the goddess's authority over the body during the affliction of poxes is "muttirai." We come across the term "muttirai" in Mariyamman songs and narratives, which confirms that the pustules of poxes are perceived to be the sovereign seal of the goddess. ${ }^{38}$ Expectedly, the religious experience, underscoring the immanent and eminent "presence" of the deity, is attuned to the predominant conception of the divine in the Tamil milieu. The Tamil term "kadavul" for "god/goddess" indicates the sense of both immanence and transcendence. Ki. Va. Jakannatan, for instance, writes: "God (andavan) is called kadavul in Tamil. It indicates his two traits. He transcends all matter (ellap porulaiyum kadantu). He is inside every matter (ellap porulkalin ullum)." ${ }^{39}$ As we shall see in the next section, the "presence" of the divine feminine in these two modes are in fact constituted through specific discourses that emerge from temple festival practices, pox-afflicted homes, songs and healer's narratives.

\section{Sprouts of the Body, Sprouts of the Field}

The discourses of Mariyamman worship are vividly marked with a couple of common iconic relationships. By "iconic relationships," I mean imagistic correlations of a "figurative kind" that eventually circulate as meaningful understandings of the afflicted body in the socio-cultural milieu. ${ }^{40}$ I invoke iconicity here because icons, by virtue of their likeness or resemblance to what they stand for, contribute to an immediacy of perception. Moreover, forging the relationship between different domains of experience in terms of likeness allows for poetic imagination to come into play. The first iconic relationship is the one shared between a pox-afflicted body and an agricultural field, and the other one is shared between an afflicted body and an anthill. ${ }^{41}$ The former, which I shall explicate in this article, opens up a way to understand how the "presence" of a divine force, as both immanent and eminent, is produced, and how the benevolence of the force figures in this enterprise. I propose that with the pox-afflicted body being imagined on par with an agricultural field, figurative correlations between pustules, pulses and grains could be advanced. On the one hand, due to the dependence of the agricultural field on rain, and their relationship on a vertical

37 As Butler observes concerning gender, materialization and signification of the body as the goddess is never a fool-proof and complete process. Like the ideal of the heterosexual gender, the goddess is an "ideal that no one can embody." See (Butler 1999, p. 176). One can certainly discern gaps and fissures in the process. This is a topic I think deserves some more research.

38 (Srinivasan 2009, pp. 34-36).

39 Jakannatan 1977, p. 84.

40 For an introductory discussion on Peircean iconic relationship of a "figurative kind," see (Reynolds 1995, p. 23).

41 In the proposition of the shared iconic field between the pox-afflicted body and the anthill, "a significant constitutive trait of the anthill, namely, the anthill being the home of serpents, is missing in the corresponding image of the pox-afflicted body, and consequently this missing part could have been supplied by creatively forging a dwelling presence within the body that manifests as pustules." For an analysis on the figurative association of a pox-afflicted body with an anthill, see (Srinivasan 2009, pp. 145-68). 
plane, a sovereign force analogous to the rain comes to be established. On the other hand, with rain drops, also called "pearls" (mazhaimuttu) producing another equivalent set of similar "pearls" of grains and pulses, thereby manifesting plenitude of the field, a dwelling, corporeal "presence" in/as the afflicted body is also forged. A song that celebrates Muttumari (meaning both "The pearl Mari" and "The rain of pearls"), a famous name of the goddess, makes these substantial connections, as we shall see. Moreover, since an agricultural field is conventionally identified with the feminine in the Tamil context, this conventional identification could have been a triggering condition for forging the "presence" as a female deity during pox-affliction.

I first thought about the common iconic field, involving the cultivated field, after I attended a performance called mulappari, meaning the "sprouting (tender) seedlings" or "sprouts" related to Mariyamman temple festivals in Aruppukkottai and Melur. Usually, the practice of growing and offering "sprouts" takes place as part of Mariyamman temple festivals throughout Tamilnadu, even though it is more popular in the temples in southern Tamilnadu, for instance, in the districts of Madurai, Virudunagar and Dindigul. ${ }^{42}$ In these districts, mulappari is a common name for sprouts, whereas, in central and north Tamilnadu, growing sprouts is typically indicated by the names palikai and navadhanya. ${ }^{43}$

The practice of mulappari consists of planting grains or pulses in pots filled with natural fertilizer, twigs of margosa, straw, sheaths of millet and maize, and soil/earth. ${ }^{44}$ The sprouts are grown, watered and taken care of, and after seven or nine days, the seedlings are cast into water. The event of casting away is called "malaiyerutal" meaning "sending off" the goddess. It is significant to note that this term is also used for the first ceremonial bath that a pox-afflicted person takes after the pustules "descend" from the body. During the period of growing mulappari, women perform dances called kummi (a dance performed with sticks in their hands or with simple clapping) and vazhttu (songs of benediction interspersed with ullulating [kulavai] sounds) going around these groups of pots with sprouts. The dances are performed either daily or on alternate days. On the last day, sprouts are taken out in a procession to the nearby Mariyamman temple, and then they are dispersed in the water resources such as tanks or rivers.

In the songs of kummi and vazhttu, the sprouts are addressed both as poxes and the goddess Mariyamman. In Tirupuvanam near Madurai, two elderly women singers Minakshi and Kaliyammal compared mulappari performance with pox-affliction, because, they said, "sowing" takes place in both

42 Kannan, the priest at the Aruppukkottai Mariyamman temple, observed:

The mulappari ceremony in Mariyamman temples becomes more significant as one travels from Pudukkottai to areas south to it, like Kamudi, Madurai, Aruppukkottai, Virudunagar and Tirunelveli.

Although the performance of carrying the decorated pots to water resources is spectacular since they are taken out in a huge procession of hundreds in Mariyamman temples located in Tamilnadu in southern Tamilnadu (like in Madurai, Melur, Aruppukkottai, Virudunagar, Nilakkottai, Andippatti, Kamudi, Tirupuvanam, etc.), the ceremony of sprouts appears to be existent in northern, north-western and central areas of the state too. I have seen a small number of pots of mulappari grown at the houses of individuals and being carried in procession in Chennai (Mogappair) and in Salem (Annatanappatti, Johnsonpet and Gugai).

43 See (Hiltebeitel 1991, p. 54). Hiltebeitel describes these terms in his discussion on sprouting ceremonies associated with the Draupadi cult in the north-central parts of Tamilnadu:

The little rite before us is known under many names, the most typical for Tamilnadu being navadhanya (Tamil navataniyam), "nine grains;" ankurarpana; "the casting or offering of sprouts" (Sanskrit); mulappari, apparently referring to the tender seedlings; palikai, the "little pots" in which the navadhanya is sown, a term that can also mean "young damsel" (Tamil lexicon) ...

44 In Melur and Kamudi, black bean (moccai) is preferred for growing the "sprouts" for the goddess. In Nilakkottai too, two or three varieties of pulses (such as karamani, tattaippayiru and moccai) are grown. Usually, "sprouts" are grown in large groups of pots in the premises of Mariyamman temples (for instance, in Melur and Aruppukkottai Mariyamman temples), but sometimes they are raised in a place common to the community. It is also common for pots from various houses to be kept in a particular house, which plays a lead role in the performance of "sprouts." In Nilakkottai, I visited one such house. 
these occasions. In Melur, I heard a female singer Dhanabhaghyam singing a kummi song, which reinforced the idea of poxes as sprouting seeds:

Like the green grams, she [Mariyamman] spreads throughout the body

Like the flat grams, she swells throughout the body

Another kummi song, sung a female singer called Bhaghyam, opened with addressing Mariyamman as poxes. The song asked the goddess to "descend" from the body part by part (for instance, head, neck, and shoulder etc.), and then described the mulappari performance. ${ }^{45}$

The connection between ammai and mulappari was also brought out by the healer Muthukkannu, who observed that the different varieties of ammai are akin to different modern rice varieties, such as IR 8 and IR 20 (modern yielding rice varieties) growing on the body. The habitual practices followed during pox-affliction and during mulappari are also strikingly similar. The sprouts are grown inside a closed space like a room and mostly in the dark, and entry to the room is strictly restricted. This restriction is similar to the restriction on allowing visitors in a pox-afflicted household. Further, the seedlings are grown for seven or nine days, a period that could be compared with the period of pox-affliction in the body.

Dhanabhagyam also told me that to grow mulappari the heart-mind should be clean (manaccuttam): "The sprouts should grow even and green. They should not rot in the pot, nor should the seedlings shrink. Only a pure/clean heart makes the sprouts grow well." When I asked her about sexual relationship at home during their growth, she said:

That is what I meant by the pure heart-mind. One should follow all that is followed during ammai. Like, the house should be wiped with water every day; no clothes should go out of the house; especially, one should not visit the house which is polluted with death or the house where the puberty ceremony of a girl is performed. It is better to avoid going to weddings too. The food should not be seasoned, nor pulses be fried or cooked with kuzambu (a side dish for rice). No fire should be lent, nor can it be borrowed.

One can recall that all these practices are adhered to during pox-affliction too, and they reinforce the resemblances between poxes and the sprouts. During my fieldwork (2006), Kaliyammal, a mulappari singer in Tirupuvanam, also gave me an account of these practices ending her narration with the statement: "Ammai and mulappari are similar (ore matiri)."

The above discussion allows us to infer that the sprouts growing in the earthen pots and pox pustules manifesting in the landscape of the body form a field of iconicity. The sprouts grown in the earthen pots are transposable into a larger scenario of an agricultural field cultivated with crops. The mutual correlations of a pox-afflicted body and a cultivated agricultural field formulate an ontological realm, which contributes to the forging of the "presence" of the divine, as I try to pinpoint in the forthcoming paragraphs.

\section{Poxes as the Shower of Grace}

A significant element pertaining to fields and cultivation is more relevant to grasping the conditions of establishment of a sovereign deity, who is in charge of pox-affliction. The celestial rain is necessary to make the grains grow and bring forth a cultivated field; and correspondingly, in considering the crops of poxes on the landscape of the body, one can speculate that a force from above has been imagined as being on par with the rain. It cannot be a mere coincidence that the term Mari, the proper name of our goddess, is also the term for rain and clouds in Tamil. The term "Mari" meaning rain appears quite frequently in classical Tamil literature, especially in classical anthologies,

45 I have discussed this term before. One can notice the term "descend" is used only for healing or making the poxes "roll down" the body, which may take place inside the body as well. 
such as Narrinai and Kuruntokai (c. 100 B.C-A.D. 250). ${ }^{46}$ And the term "Mari" does not refer to disease in these classical texts. In contemporary Tamil as well, the term denotes rain: for instance, one can consider the Tamil expression: "There should be three rains (mummari) in a month." A song from the Tamil film Uzhavan (1993) begins with the line, "Won't mari-rain (mari-mazhai) pour to end the famine of the people?" This suggests that the figurative resemblances between the body with poxes and the agricultural field could have played a seminal role in the naming of the deity as "Mari." It is possible that a phantasmatic celestial force, involving in the manifestation of poxes, is conceived analogous to the celestial rain, which is instrumental in bringing forth the cultivated field, and consequently, the name "Mari" came to be shared by the rain and the deity. The identification with rain also explains how the deity is perceived as benevolent in bestowing poxes.

A song that I heard from Rajamma, a healer of ammai from Nattam near Dindigul in the year 2006, equates the goddess with rain: "If you say Mari, the rains would flow; If you say Devi, honey would flow." In a palm-leaf manuscript version of the Talattu, the description of the goddess Muttumari ("Pearl Mari") "playing virulently" conflates the images of the pouring rain and the shower of poxes on the body, thereby bringing the goddess's benevolence to the foreground:

Has she arrived here playfully with a poor pretext

For dwelling in me, considering me as poor? ...

Is she the wealth of rain hiding the sun? ...

Has she arrived to play virulently?

Is she the relentless Pearl Mari, who, for the red rice to grow

Roared as thunder with lightning and showered as rains from the clouds?

With the sky becoming dark and the sunlight fading

Has she stood blessing the flow of rain (Mari)? ${ }^{47}$

The pearls of rain embrace the earth producing another set of pearls like grains, pulses, and pearls of other crops that bud forth. An excerpt from this text further addresses her as all these pearls:

Is she the mother pearl, pearls of rain, pearls of ammai, or of sugarcane?

Is she pearls of bamboo, or of red paddy, or the playful Marimuttu ${ }^{48}$

While as pearls of rain, Muttumari metonymically stands for and ensures earthly plenitude, as the sprouting pearls of the earth, she is the embodiment of plenitude. As the sprouting seeds of crops, Muttumari constitutes the cycle of birth of crops, their growth, harvest and re-entry into the earth through sowing; and as rain, she ensures that the seeds grow. Inasmuch as pearls of poxes are located on par with other types of pearls of crops, the pearls of poxes that sprout on the body correspond with these earthly seeds and are considered as plenitude and prosperity. At the same time, since the description of the goddess "playing virulently" comes along with the description of Mariyamman as the rain, the pearls of poxes replicate and correspond with the celestial rain pearls, ensuring such plenitude and prosperity.

Further, as the deity of poxes is conceived on par with rain, the traits of rain, namely generosity and impartiality, often praised and celebrated in Tamil classical texts like Tirukkural, Narrinai, and Kuruntokai, mark the nature of the deity too. The goddess's throwing pearls of poxes at will and in all directions devoid of bias is a narrative pattern that one comes across in songs. For instance, "The Story of Sri Mariyamman" celebrates the goddess's taking measures of various sizes used to weigh grains

46 The term 'Mari,' meaning rain and clouds, appears in Narrinai and Kuruntokai. See (Narrinai, verses 141, 190, 192, 244, 253, $265,312,314,334,379,381$ ) and (Kuruntokai, verses 66, 91, 94, 98, 117, 161, 168, 200, 222, 251, 259, 289, 319). Although the twentieth century Tamil lexicon gives other meanings of the term "Mari" such as death and ammai, it is worth noting that "Mari" does not have these negative significations in the earlier classical anthologies.

47 (D 1747, lines 93-104).

48 (Ibid., lines 71-72). I have taken some liberty in this translation: at one place I have translated "Marimuttu" as the pearls of rain and another place I simply retain it as her proper name since both translations are relevant. 
and throwing pearls on people in all directions without bias. ${ }^{49}$ The generosity and impartiality of the goddess, derived primarily from the image of the rain, is extended to her justly distributing earthly plenitude. Consider, for instance, a song of benediction rendered by a woman called Lakshmi from Aruppukkottai on mulappari:

The rain pours in the north, the water flows along the fields

The ducks swim across the waterways

The crane flies, the rice is being sown

Since the low caste Pallars who have sown the rice go hungry,

The Ati Para Eswari (the primordial goddess) opens the granary

And comes to bestow the grains in measures of padis

Make, Make the ullulating sound of the ornament of golden gems.

The concern of the goddess for the hungry have-nots, here, the laborers of the land who are alienated from their labor, which makes her bestow the rice grains on them, is transposed into her grace and protection during the affliction. Similarly, in Mariyamman Patam, poxes are represented as an ornament of pearls that embraces the body and "protects" one in the face of "differences" encountered in the world:

Like an ornament of pearls, Mother

You have embraced me so that you can protect me

From differences .... .50

Perhaps this is because in this world of rich and poor, the pearls of poxes show no prejudice and ensure a possibility that they could arrive upon anyone erasing all differences. The Talattu explains this idea better when it articulates that the goddess has taken all the pearls of the world in order to divide them [among people] equally without any bias or prejudice. ${ }^{51}$ The text further praises her as the one who "lavishes a boon of flowing pearls even upon those who have none by their side, asking them to fear not." ${ }^{2}$

In the above passages, based on ethnographic materials and literary evidences, I have suggested the ways through which Mariyamman is simultaneously constituted as a corporeal "presence" as well as an autonomous force determining the fate of human beings during pox-affliction. The plenitude ensured by the rain seems to have been transformed into the benevolent attribute of the deity. A temple legend, gathered from Tiruverkadu on Karumari, confirms the association of the goddess with rain. While silent on the subject of poxes, the temple legend establishes the goddess as a sovereign deity pertaining to a sacred place (sthalam) through reworking the equivalence between her compassion and the benevolence of rain. In the name "Karumari," the adjective "karu" denotes "black/dark," and "Mari," as already stated, denotes "rain," and metonymically "(rain) cloud." The story was narrated by Kuttiyappa Mudaliyar, whose forefathers participated in founding the temple of Karumari in Tiruverkadu:

Our family gave the land for the Tiruverkadu temple in 1937. Before that there were Harijans (Dalits) who were fortune-tellers (kuri solpavarkal, meaning diviners) at this place. They used to give life sacrifices such as goats to the goddess Karumari. As my father and other neighbors were opposed to that practice, they left for another place called Perumalagaram, and from there, they continued with their fortune-telling. It so happened that my father at one point went to get his fortune told by them. The goddess said [through the fortune-tellers]:

\footnotetext{
49 This song (n.d.) has been published as a chapbook by a woman's group in Aruppukkottai.

50 (D 1750, lines 17-20).

51 (D 1747, lines 21-22).

52 (Ibid., lines 23-24).
} 
"You deprived me of my home. If you find a place as home for me, then I will save you for seven generations." On hearing that, we gave away the land, and she has kept us happy.... Karumari means karumukil (the dark cloud). She bestows compassion upon us like the rain that protects the world.

\section{Conclusion: The Deity of Poxes as Female Power}

The above discussions have mapped how the super-human, autonomous force or deity presiding over poxes and manifesting as poxes could have been imagined, but the constitutive conditions of the deity's gender have not been hitherto explored. In the classical Tamil texts we do not encounter a decisive identification of rain with any particular gender. ${ }^{53}$ However, the figure of the agricultural field itself offers help with this enterprise. It is important to note that both uncultivated land and cultivated agricultural field are articulated as female in Tamil literary sources. For instance, expressions, such as "nilamennum nallal" meaning "the good woman called land/field" or "nilam pulantillal" meaning "the housewife that is the field of land/field" appear in the second century didactical text Tirukkural. ${ }^{54}$ One can also see the explicit sexual suggestion linking a woman with the agricultural field, which is ready for cultivation in the text Kuruntokai. ${ }^{55}$ Since the agricultural field and the pox-afflicted body coexist in the same ontological realm, such sharing could have paved the way for identifying the landscape of the body, sprouting crops of poxes, with the feminine. With the pox-afflicted body being identified with the feminine, this gender identity could have been attributed to the dwelling "presence" of the force forged in the afflicted body. Inasmuch as this "presence" is simultaneously perceived analogous to the rain or "mari" from above, the autonomous and sovereign force could be constituted as the female deity Mari.

In the Tamil milieu, the religious experience of pox-affliction, as foregrounded in songs, narratives, and temple festival and healing practices, is predicated on invoking the goddess in her manifestations as pox-afflicted body and as a super-human power. At the same time, such experience is creatively invested with figurative expressions, including metaphors, metonymies and imagistic correlations, and complex multi-layered equivalences between terms, summoning a new kind of understanding while opening the doors necessary to accomplish it. Decoding the immanent and eminent manifestations of the goddess, in the course of emphasizing how the "presence" of the goddess is discursively forged in constructing these manifestations, is taking one step in that direction, which this essay endeavors to do.

Funding: This research was partly funded by a Junior Scholar Dissertation Research Fellowship by the American Institute of Indian Studies between 2005 and 2006.

Conflicts of Interest: The author declares no conflict of interest.

\section{References}

\section{Primary Sources}

Tamil

Manuscripts (Government Oriental Manuscripts Library, Chennai)

Mariyamman Talattu. n.d. D1747.

Mariyamman Peril Patam. n.d. D1750.

Mariyamman Varnippu. n.d. D 2164.

Texts

53 In classical literary texts, we find references to rain in connection with both sexes. For instance, the generosity of a male patron is compared to the generous rain. See (Purananuru, verse 142). In Kuruntokai, the cool eyes of the heroine are described as "mazaikkan" or "rainy eye." See (Kuruntokai, verses 72, 86, 222, 259, 286, 329).

54 See (Tirukkural, Chapter "Plough," verses 1040 and 1039).

55 See (verse 131). 
Jakannathan, Ki. Va. 1977. Tamil Nul Arimukam. Chennai: Amuta Nilaiyam.

Kuruntokai. Text and commentary. 1985. Ed. Mu. Canmukam Pillai. Thanjavur: Tamil University.

Mariyamman Talattu. N.d. Erode: Mathi Books.

Narrinai. Text and commentary. 1966-68. Com. Avvai Cu Turaicamippillai. Chennai: Aruna Publications.

Purananuru. 1967-72. Text and commentary. Com. Avvai Cu Turaicamippillai. Tirunelveli: Tennintiya Caiva Cittanta Nurpatippuk Kalakam.

Srimuttumariyamman Mulappari Kummippadalkal. N.d. Aruppukkottai: Ekadasi Women's Group.

Tiruvalluvar. Tirukkural. Text and commentary. 2000. Com. Manakkutavar. Edited by T. Racagopalan. Chennai: Aintinaippatippakam.

\section{Secondary Sources}

Arnold, David. 1993. Colonizing the Body: State Medicine and Epidemic Disease in Nineteenth-Century India. Delhi: Oxford University Press.

Bellamy, Carla. 2008. Person in Place: Possession and Power at an Indian Islamic Saint Shrine. Journal of Feminist Studies in Religion 24: 31-44. [CrossRef]

Bloomer, Kristin. 2018. Possessed by the Virgin: Hinduism, Roman Catholicism, and Marian Possession in South India. New York: Oxford University Press.

Butler, Judith. 1993. Bodies that Matter: On the Discursive Limits of "Sex.". New York: Routledge.

Butler, Judith. 1999. Gender Trouble: Feminism and the Subversion of Identity. New York: Routledge.

Caldwell, Robert. 1887. On Demonology in Southern India. The Journal of the Anthropological Society of Bombay 1: 91-105.

Dubianski, Alexander M. 2000. Ritual and Mythological Sources of the Early Tamil Poetry. Groningen: Egbert Forsten. Egnor, Margaret Trawick. 1984. The Changed Mother or What the Smallpox Goddess Did When There was No More Smallpox. Contributions to Asian Studies XVIII: 24-45.

Erndl, Kathleen M. 1993. Victory to the Mother: The Hindu Goddess of Northwest India in Myth, Ritual, and Symbol. New York: Oxford University Press.

Foucault, Michel. 1972. The Archaeology of Knowledge and the Discourse on Language. Translated by A. M. Sheridan Smith. New York: Pantheon Books.

Foucault, Michel. 1985. The Use of Pleasure. Translated by Robert Hurley. New York: Vintage Books.

Foucault, Michel. 1991. Remarks on Marx: Conversations with Duccio Trombadori. Translated by R. James Goldstein, and James Cascaito. New York: Semiotext(e).

Foulston, Lynn. 2002. At the Feet of the Goddess: The Divine Feminine in Local Hindu Religion. Portland: Sussex Academic Press.

Hancock, Mary Elizabeth. 1995. Dilemmas of Domesticity. In From the Margins of Hindu Marriage. Edited by Lindsey Harlan and Paul B. Courtright. New York: Oxford University Press, pp. 60-91.

Hancock, Mary Elizabeth. 1999. Womanhood in the Making: Domestic Ritual and Public Culture in Urban South India. Colorado: Westview Press.

Harman, William. 2011. Possession as Protection and Affliction: The Goddess Mariyamman's Fierce Grace. In Health and Religious Rituals in South Asia: Disease, Possession and Healing. Edited by Fabrizio M. Ferrari. New York: Routledge, pp. 185-98.

Hiltebeitel, Alf. 1991. The Cult of Draupadi: On Hindu Ritual and the Goddess. Chicago: University of Chicago Press, vol. 2.

Marriott, McKim, and Ronald B. Inden. 1977. Toward an Ethnosociology of South Asian Caste Systems. In The New Wind: Changing Identities in South Asia. Edited by Kenneth David. The Hague: Mouton Publishers, pp. 227-38.

McDaniel, June. 2009. Religious Experience in Hindu Tradition. Religion Compass 3: 99-115. [CrossRef]

Nabokov, Isabelle. 2000. Religion against the Self: An Ethnography of Tamil Rituals. New York: Oxford University Press.

Reynolds, Dee. 1995. Symbolist Aesthetics and Early Abstract Art: Sites of Imaginary Space. Cambridge and New York: Cambridge University Press.

Shuttleton, David E. 2007. Smallpox and the Literary Imagination, 1660-1820. Cambridge and New York: Cambridge University Press. 
Smith, Frederick M. 2006. The Self Possessed: Deity and Spirit Possession in South Asian Literature and Civilization. New York: Columbia University Press.

Smith, Frederick M. 2011. Possession in Theory and Practice: Historical and Contemporary Models. In Health and Religious Rituals in South Asia: Disease, Possession and Healing. Edited by Fabrizio M. Ferrari. New York: Routledge, pp. 3-16.

Srinivasan, Perundevi. 2009. Stories of the Flesh: Colonial and Anthropological Discourses on the South Indian Goddess Mariyamman. Ph.D dissertation, The George Washington University, Washington, DC, USA.

Wadley, Susan S. 1980. Sitala: The Cool One. Asian Folklore Studies 39: 33-62. [CrossRef]

(C) 2019 by the author. Licensee MDPI, Basel, Switzerland. This article is an open access article distributed under the terms and conditions of the Creative Commons Attribution (CC BY) license (http:/ / creativecommons.org/licenses/by/4.0/). 